\title{
A glance at one decade of water pollution research in Iranian environmental health journals
}

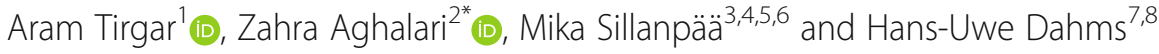

\begin{abstract}
Background: Due to the importance of water, the negative effects of water pollution on human health and the lack of proper knowledge of the state of research in this regard, the purpose of this study was to analyse scientific publications on water pollution in Iranian journals of environmental health.
\end{abstract}

Methods: This cross-sectional study was conducted using a scientometric method over a ten-year period (20082017) on articles published in five specialised environmental health journals emphasising the issue of water pollution. Data were collected through a researcher-based checklist using the International Committee of Medical Journal Editors (ICMJE) and the World Association of Medical Editors (WAME) recommendations. Data processing was done using descriptive statistics and VOSviewer software.

Results: A review of 1276 articles in specialised environmental health journals revealed that $33.7 \%$ of the articles were in the field of water. Physical and chemical factors in water were the main subjects of $21.4 \%$ of studies, and temperature and turbidity were the most important physical factors. Microbial agents in groundwater and surface water were the main subjects of $14.1 \%$ of the articles. The findings show that 55 of 430 articles related to water were written with contributions from 20 countries (including Iran), with the most contributions from researchers from Asia.

Conclusions: Good conditions do not exist to investigate the status of articles on water pollution in specialised environmental health journals in Iran over a ten-year period. Health policymakers should therefore provide mechanisms to encourage national researchers, especially environmental health professionals, by setting national research priorities on quality and water pollution to conduct studies in this regard.

Keywords: Water pollution, Environmental health, Articles, Journals, Scientometrics

\section{Introduction}

Water accounts for two-thirds of human body weight. This indicates that water is a vital ingredient for human survival and attention to water pollution is important (Aghalari and Jafarian 2017; Dai etal. 2016). In contrast, contaminated water, in addition to compromising human health, has a

\footnotetext{
* Correspondence: z.aghalari@gmail.com

${ }^{2}$ Faculty of Public Health, Gonabad University of Medical Sciences, Gonabad, Iran

Full list of author information is available at the end of the article
}

detrimental effect on the various aspects of human life, including social, economic and cultural (Satterthwaite 2016; Behailu etal. 2016). According to a report by the United States Environmental Protection Agency (EPA), about one-third of the world's water is polluted. In this report, pollution is a factor damaging the chemical, physical and aesthetic properties of water (Komasi and Sharghi 2017). Since 2004, the World Health Organization (WHO) has been recommending the Water Safety Plan (WSP) to reduce the pollution of drinking water, 
Table 1 Specifications of Iranian environmental health specialist journals (2008-2017)

\begin{tabular}{|c|c|c|c|c|c|c|}
\hline Journal name & $\begin{array}{l}\text { The first } \\
\text { year of } \\
\text { publication }\end{array}$ & Language & $\begin{array}{l}\text { Journal } \\
\text { abbreviation }\end{array}$ & $\begin{array}{l}\text { Kind of } \\
\text { publication }\end{array}$ & Publisher & Website Address \\
\hline $\begin{array}{l}\text { Journal of Environmental } \\
\text { Health Science and } \\
\text { Engineering }\end{array}$ & 2004 & English & JEHSE & $\begin{array}{l}\text { Published } \\
\text { Quarterly }\end{array}$ & $\begin{array}{l}\text { Tehran University } \\
\text { of Medical } \\
\text { Sciences }\end{array}$ & $\begin{array}{l}\text { https://www.springer.com/environment/ } \\
\text { environmental+health+-+public+health/ } \\
\text { journal/40201 }\end{array}$ \\
\hline $\begin{array}{l}\text { Environmental Health } \\
\text { Engineering and } \\
\text { Management Journal }\end{array}$ & 2014 & English & EHEMJ & $\begin{array}{l}\text { Published } \\
\text { Quarterly }\end{array}$ & $\begin{array}{l}\text { Kerman University } \\
\text { of Medical } \\
\text { Sciences }\end{array}$ & http://ehemj.com/ \\
\hline $\begin{array}{l}\text { Iranian Journal of Health } \\
\text { and Environment }\end{array}$ & 2008 & Persian & IJHE & $\begin{array}{l}\text { Published } \\
\text { Quarterly }\end{array}$ & $\begin{array}{l}\text { Tehran University } \\
\text { of Medical } \\
\text { Sciences }\end{array}$ & $\begin{array}{l}\text { http://ijhe.tums.ac.ir/index.php?\&slct_pg_ } \\
\text { id=10\&sid=1\&slc_lang=en }\end{array}$ \\
\hline $\begin{array}{l}\text { Journal of Environmental } \\
\text { Health Engineering }\end{array}$ & 2013 & Persian & JEHE & $\begin{array}{l}\text { Published } \\
\text { Quarterly }\end{array}$ & $\begin{array}{l}\text { Alborz University } \\
\text { of Medical } \\
\text { Sciences }\end{array}$ & $\begin{array}{l}\text { http://jehe.abzums.ac.ir/index.php?slc_ } \\
\text { lang=en\&slc_sid=1 }\end{array}$ \\
\hline $\begin{array}{l}\text { Journal of Research in } \\
\text { Environmental Health }\end{array}$ & 2015 & Persian & JRHE & $\begin{array}{l}\text { Published } \\
\text { Quarterly }\end{array}$ & $\begin{array}{l}\text { Mashhad } \\
\text { University of } \\
\text { Medical Sciences }\end{array}$ & $\begin{array}{l}\text { http://jreh.mums.ac.ir/journal/about?lang= } \\
\text { en }\end{array}$ \\
\hline
\end{tabular}

but there are still contaminants in water resources that, in addition to serious damage to human and environmental health, lead to death in different parts of the world (WHO 2008). In the United Nations World Water Development Report (2015), 1.1 billion people in the world do not have access to safe drinking water, $90 \%$ of whom live in continental Asia and Africa (The United Nations world water development report 2015).

According to the above, conducting water-related research and its contaminating agents are necessary measures to protect water resources (Ikonen etal. 2013; Fisher etal. 2015). Continuous assessment of water quality and the publication of findings on water pollution in the form of articles and scientific reports have led to the production of a set of information that, at the time of the occurrence of epidemics and acute environmental problems, gives a detailed picture of water quality, and the identification and elimination of factors causing pathogenic agents in water (Yan etal. 2015).

Scientometrics or citation analysis is one of the new scientific approaches that can be used to monitor scientific activities and manage research (Tirgar and Aghalari 2018; Aghalari and Tirgar 2017), so scientometrics is one of the research methods used for quantitative research on scientific production, scientific policy and a scientific plan (Saj)adi et al., 2018) for protecting water resources and preventing their pollution. Considering the importance of water, the negative effects of water pollution on human health and the lack of accurate information on the state of research in this regard, the purpose of this study was to analyse scientific publications on water pollution in the Iranian journals of environmental health.

\section{Materials and methods}

This descriptive study was carried out retrospectively for a period of ten years on all articles published in the Iranian Journal of Environmental Health focusing on water pollution, from the beginning of 2008 to the last issue published in 2017. The inclusion criteria were the existence of the phrase 'environmental health' in the title of the journal, the publication of at least four issues of journals per year and the publication of articles in three consecutive years. According to the aforementioned criteria, three Persian-language journals and two Englishlanguage journals were selected (Table 1).

Data collection was done by logging into the dedicated site of each journal and downloading all the articles. The related articles, their titles, abstracts and keywords were then reviewed individually and the articles related to water were eventually enrolled in the study (Fig. 1).

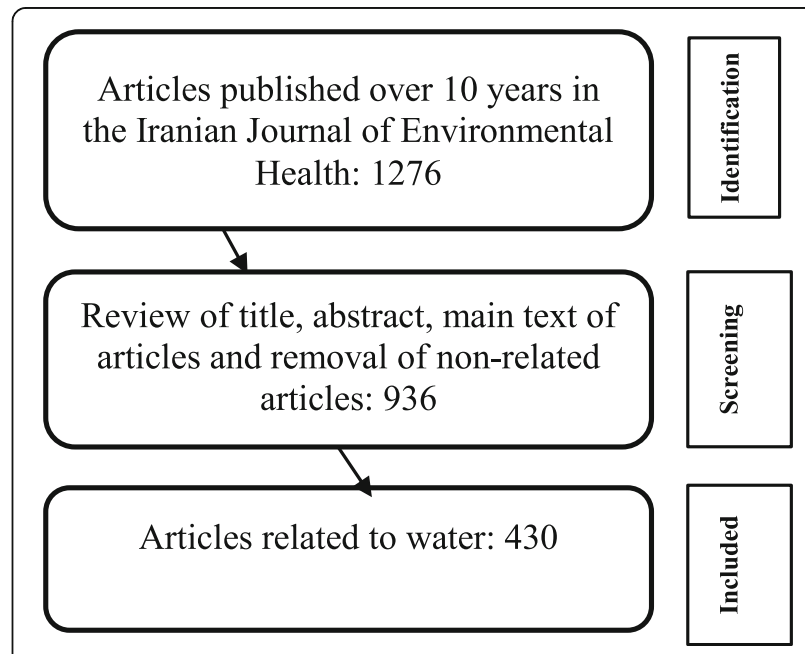

Fig. 1 The process of searching for, reviewing and selecting waterrelated articles in the Iranian Environmental Health Specialist journals 
Table 2 Variables studied about water in specialised environmental health journals (2008-2017)

\begin{tabular}{|c|c|}
\hline Variables & Levels \\
\hline Water-related articles by journals & Number / percent \\
\hline $\begin{array}{l}\text { Water-related articles by year of } \\
\text { publication }\end{array}$ & Number / percent \\
\hline Sources of water & 1- Surface 2-Groundwater \\
\hline Types of pollutants by origin & $\begin{array}{l}\text { 1- Primary pollutants } 2 \text { - Secondary } \\
\text { pollutants }\end{array}$ \\
\hline Physical variables & Classification by type \\
\hline Microbial agents & Classification by type \\
\hline Heavy metals & Classification by type \\
\hline Chemical pollutants & Classification by type \\
\hline $\begin{array}{l}\text { Collaboration of researchers by } \\
\text { country }\end{array}$ & Name of countries \\
\hline $\begin{array}{l}\text { Collaborative research by } \\
\text { continent }\end{array}$ & Name of continent \\
\hline
\end{tabular}

Data collection was done by a researcher-made checklist about which there was previous experiences (Tirgar et al., 2019; Aghalari et al., 2020). To select the most important and common variables, recommendations for articles in the formulation of articles by the International Committee of Medical Journal Editors (ICMJE 2019) and the World Association of Medical Editors (World Association of Medical Editors (WAME) and Editorial Policy and Publication Ethics Committees, 2019) were the criteria of choice. The research encompassed the variables studied for analysing the articles, the number of articles by journals and the year of publication, type of pollutant, sources of water surveyed and the geographical distribution of the researchers (Table 2).

\section{Data anlysis}

After collecting the data, the information about the articles studied was encoded and entered into Excel software. The data were processed statistically using descriptive statistics. VOSviewer software was also used to visualise the data and show the level of collaboration of continents and authors from different countries with Iran. This software helped to visualise the collaborative network of authors from different countries in different ways. For example, it made it possible to display data aggregate by different colours, clustering them at different geographic locations (Van Eck and Waltman 2009).

\section{Results}

\section{Articles according to journals}

A review of 1276 articles in 102 issues over the past decade (2008-2017) were published in five Iranian Journal of Environmental Health, with 430 articles (33.7\%) related to water. The highest and lowest proportion of water-related articles belonged to JEHSE and JRHE, contributing $36 \%$ and $7 \%$, respectively. The shares of IJHE, JEHE and EHEMJ in the publication of papers were 34\%, $15 \%$ and $8 \%$, respectively.

\section{Trend of articles publications}

According to the findings, a survey of the trend of published articles in the field of water during the past decade shows that, despite the fluctuations, the number and proportion of water-related articles grew in environmental health publications. As shown in Fig. 2, in total, over a decade, there has been an uptrend in the publication of water articles (Fig. 2).

\section{Type of water resources}

In the present study, in terms of type of water resources, surface water was classified into eight categories and

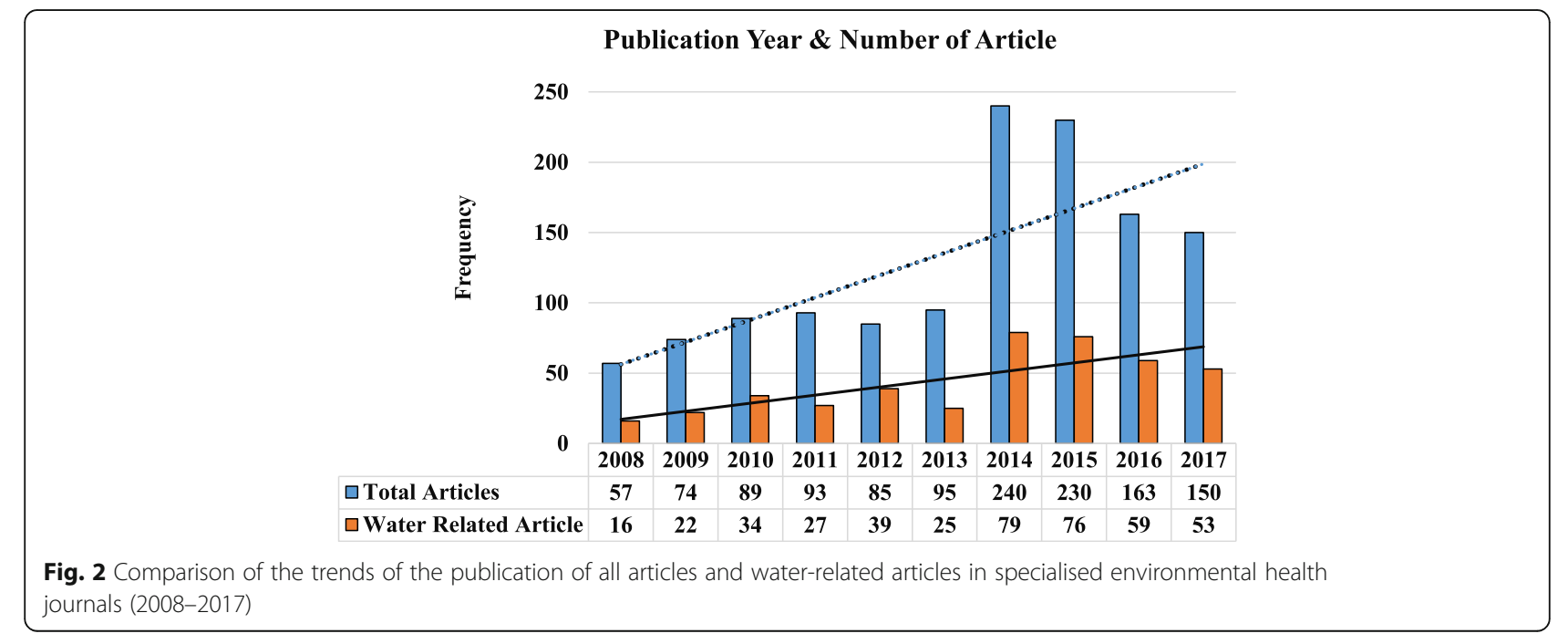


Table 3 Frequency of water resources in water studies in Iranian environmental health journals (2008-2017)

\begin{tabular}{llll}
\hline Water resources & Types & Number & Percentage \\
\hline Surface water & Drinking water & 211 & 49.1 \\
& *Surface water & 63 & 14.6 \\
& River, lake and sea & 55 & 12.8 \\
& Swimming pools & 13 & 3.1 \\
& Surface runoffs & 10 & 2.3 \\
& Haemodialysis water & 5 & 1.2 \\
Groundwater & Wetland & 4 & 1 \\
& * Ground water & 37 & 8.6 \\
& Spring water & 16 & 3.7 \\
Total & Wells water & 9 & 2.1 \\
& & 430 & 100
\end{tabular}

* In a number of articles, the type of water resources was not explicitly mentioned, and only the authors cited examples of surface water and groundwater, so two separate categories for surface water and groundwater were mentioned

groundwater into three (Table 3). Most of the water resources belonged to surface water (368 articles (85.5\%)). Drinking water had the highest abundance of surface water (Table 3).

\section{Type of water pollutants}

The classification of articles based on the type of water pollutants into primary and secondary categories (according to EPA classification) showed that most pollutants in 280 articles (65.1\%) fall in the category of primary contaminants (such as microbial, chemical, organic, mineral, disinfection products, radionuclides, antibiotics), and 93 articles $(21.7 \%)$ in the category of secondary pollutants (physical pollutants, heat, cold, turbidity, aesthetic (taste, odor, and colour) (Table 4).

According to the findings, among 430 articles related to water, in 92 articles (21\%) the physical and chemical factors were the main subject of the study. Temperature and turbidity are very important physical factors, which were examined in 58 and 57 articles. Among the chemical properties of water, corrosion was studied with the least frequency in just two articles (Table 5).

According to the findings, 52 articles (12\%) were devoted to the determination of the amount and environmental effects of 15 heavy metals in water resources, with the highest frequency for chromium (30 articles), cadmium (29 articles) and lead (27 articles) (Fig. 3).

According to the findings, in 212 articles (49\%), chemical compounds in water were the main subjects of the research. Among the various chemical compounds, the most frequent were nitrates (45 articles), and phenol (36 articles) (Fig. 4).

According to findings from 430 articles, in 61 (14.1\%) about microbial agents in surface and ground water, the highest number of microbial agents studied was related to different types of bacteria, and the numbers of published articles on the study of fungus, parasites and viruses in water were 5, 2 and 1 (Table 6).

\section{Collaboration in research}

The findings show that there was international research participation in 55 articles (12.7\%). In Fig. 5, researchers' collaborative network was drawn to continents and countries using VOSviewer software (Fig. 5). According to this figure, there were 25 nodes (mutual cooperation) and 199 authors from 20 countries participating in the research. In this network, the size of each node represents the total number of articles from each country and continent with Iran, and the diameter of the link between the two nodes is proportional to the number of joint writings. Since the collaboration of countries with Iran was targeted in this study, Iran was located at the centre of the nodes with 55 articles. In this map, countries with more contributions by Iranian authors were located closer to Iran and less contributing countries more distantly. According to the findings, the top continents based on the number of articles shared with Iran were Asia, Europe and Africa with 37, 9, and 7 articles, respectively. From the perspective of countries, India had the highest level of cooperation with Iranian researchers with 8 articles (Fig. 5).

\section{Discussion}

The findings of the present study showed that more than $30 \%$ of the 1276 articles published over the last decade in environmental health journals were devoted to water issues. In a study by the WHO in 2012, with the collaboration of 14 research institutes around the world, the burden of water-borne diseases was higher in 145 countries with a low-to-moderate income level. According to

Table 4 Types of primary and secondary pollutants in water studies in Iranian environmental health journals (2008-2017), by EPA classification

\begin{tabular}{llll}
\hline Type of water pollutants & Pollutant & Number & Percentage \\
\hline Primary pollutants & Microbial, Chemical, Organic, Mineral, Disinfection, Radionuclides, Antibiotics & 280 & 65.1 \\
Secondary pollutants & Physical pollutants, Heat, Cold, Turbidity, Aesthetic (taste and odor), colour & 93 & 21.7 \\
Both types & Primary and secondary pollutants & 57 & 13.2 \\
Total & & 430 & 100 \\
\hline
\end{tabular}


Table 5 The frequency of physical and chemical variables in water studies in Iranian environmental health journals (2008-2017)

\begin{tabular}{|c|c|c|c|}
\hline Variables & Types & Number* & Percentage \\
\hline \multirow[t]{3}{*}{ Physical properties of water } & Temperature & 58 & 13.4 \\
\hline & Turbidity & 57 & 13.2 \\
\hline & Aesthetic (taste and odor) & 2 & 0.46 \\
\hline \multirow[t]{5}{*}{ Chemical properties of water } & Acidity & 44 & 10.2 \\
\hline & Hardness & 34 & 7.9 \\
\hline & Electrical conductivity & 21 & 4.8 \\
\hline & Oxygen & 8 & 1.8 \\
\hline & Corrosive & 2 & 0.46 \\
\hline
\end{tabular}

* Due to the two or multiple themes of some articles, each of the research topics is more than the full range of articles related to the physical and chemical properties of water

the WHO report, 502,000 deaths due to water pollution occurred in the Southeast Asian and African countries. In the Mediterranean countries including Iran, 50,400 deaths were registered, with 432 deaths due to water pollution in Iran (WHO 2014). Obviously, water pollution, causing diseases and related deaths are highlighted by environmental health professionals by conducting more and more research into the identification of water contamination factors, thus providing effective and diverse water contamination prevention strategies.

In the present study, in $21.4 \%$ of the articles physical and chemical factors were the main subject of the water studies, and the most important physical factors were temperature and turbidity. Studies in drinking water in Philadelphia, Atlanta and Vancouver showed a positive relationship between turbidity and endemic digestive diseases (Hsieh etal. 2015). The study by Yao et al. (2016) showed that turbidity in the Taihu River of China was directly related to the concentration of heavy metals. Turbidity is one of the symptoms of microbial contamination in water, which requires further research to identify its association with other chemical and mineral pollutants.

In this study, 52 articles were devoted to the determination of the amount and environmental effects of heavy metals in water resources, which of 52 articles are listed in attached 1.(Attach1(Ref.1-52)). Because this study showed that most of articles were about dangerous pollutants such as chromium (30 articles), cadmium (29 articles) and lead (27 articles), it is suggested that in future research, these articles be studied to servey the pollutants in water resources. One of the highest heavy metals in the articles were cadmium and lead respectively. In a study by $\mathrm{Fu}$ et al. (2013), a survey of drinking water research published in the ISI database from 1992 to 2011 showed that most heavy metals were arsenic, lead and cadmium, which are similar to the findings of this study. Heavy metals are persistent and non-degradable pollutants (Ab Razak et al., 2015). Although some heavy metals are essential for biosynthesis in humans, however,

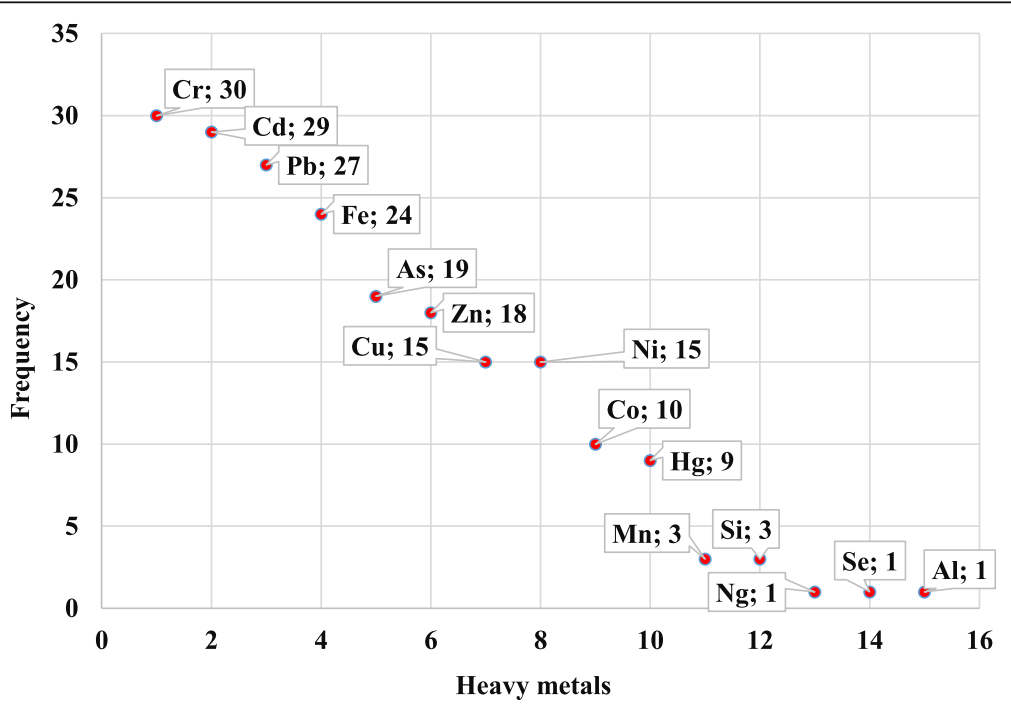

Fig. 3 Frequency of heavy metals in water studies in Iranian environmental health journals (2008-2017) 


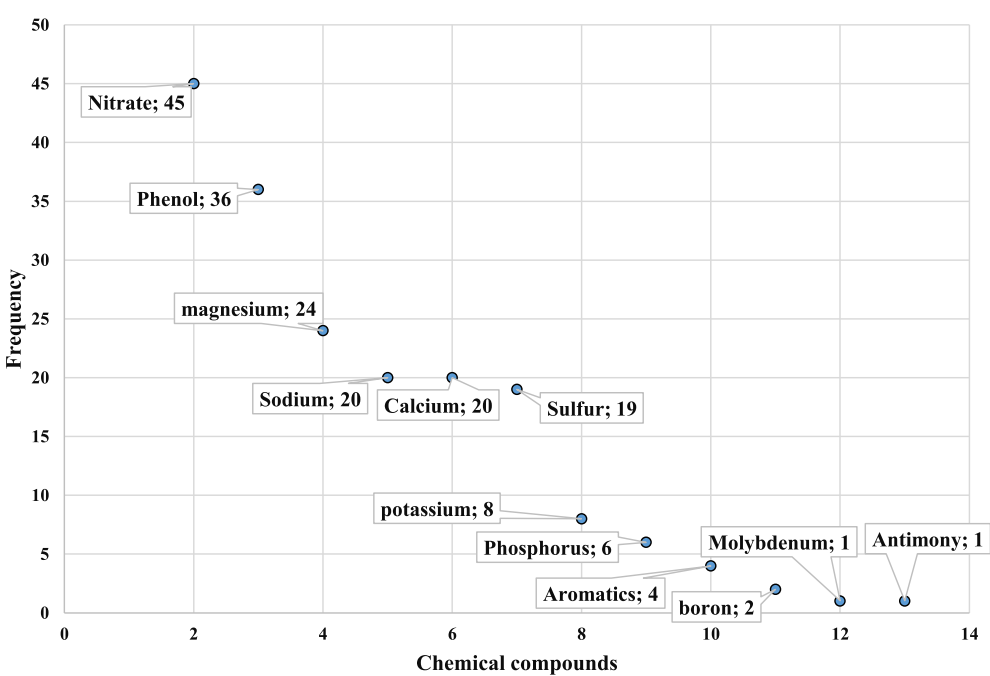

Fig. 4 Frequency of chemical compounds in water studies in Iranian environmental health journals (2008-2017)

some metals such as lead and chromium, even at very low concentrations, have negative effects on human health (Abraham and Susan 2017; Li et al. 2012; Adesiyan et al. 2018). Therefore, conducting extensive research, identifying contaminated resources and providing control strategies from the missions of environmental health professionals are very important.

In the present study, the main topic in $14.1 \%$ of the articles was the study of microbial agents in surface water and ground water, and the highest number of microbial agents studied was related to different types of bacteria. A study by Chen et al. (2016) showed that contaminants in the surface water of the Liao River included faecal contamination, oil and organic pesticides. A study by Kirschner et al. (2017) on the pollution of the River Danube showed that a major contamination was faecal. A study by Glińska-Lewczuk et al. (2016) showed that the highest contamination of the Łyna River in Poland was bacterial, so the findings of this study, like our research, indicate that microbial testing should be carried out continuously in drinking water to solve this problem.

In this study, the classification of the 55 articles written with the contribution of 199 researchers from 20

Table 6 Frequency of microbial agents in in water studies in Iranian environmental health journals (2008-2017)

\begin{tabular}{|c|c|c|c|}
\hline Microbial contamination & Types & Number & Percentage \\
\hline \multirow[t]{11}{*}{ Bacteria } & Faecal coliforms & 37 & 8.6 \\
\hline & Heterotrophic plate counts & 11 & 2.5 \\
\hline & Staphylococcus aureus & 5 & 1.6 \\
\hline & Escherichia coli & 5 & 1.6 \\
\hline & Pseudomonas aeruginosa & 5 & 1.6 \\
\hline & Bacillus subtilis & 3 & 0.7 \\
\hline & Streptococcus faecalis & 3 & 0.7 \\
\hline & Acinetobacter & 2 & 0.5 \\
\hline & Klebsiella pneumoniae & 2 & 0.5 \\
\hline & Aeromonas & 1 & 0.2 \\
\hline & Achromobacter & 1 & 0.2 \\
\hline \multirow[t]{3}{*}{ Mycological flora } & Aspergillus & 3 & 0.7 \\
\hline & Mycotic flora & 1 & 0.2 \\
\hline & Candida & 1 & 0.2 \\
\hline \multirow[t]{2}{*}{ Parasite } & Giardia & 1 & 0.2 \\
\hline & Legionella & 1 & 0.2 \\
\hline Virus & Norwalk virus & 1 & 0.2 \\
\hline
\end{tabular}




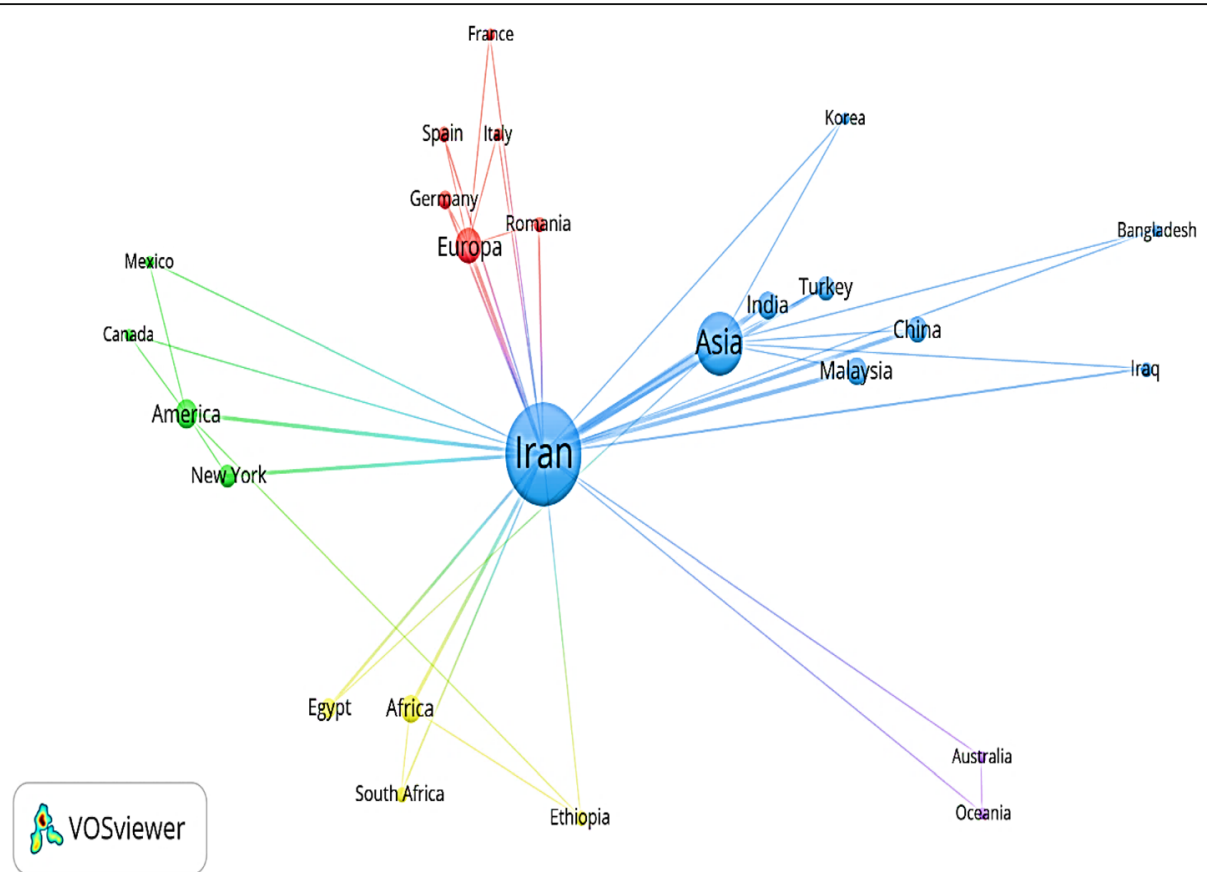

Fig. 5 Collaborative network of authors of joint water studies in Iranian environmental health journals based on continents and countries (2008-2017)

countries (including Iran) showed that the highest number of articles published in Iran was shared by Asian scholars. The study by Sweileh on the study of scientific publications on water-borne diseases at the Scopus showed that most countries that had scientific cooperation in the field of water diseases were European, North American, Asian and Australasian (Sweileh et al. 2016). Given the research facilities and funding available for health projects in European and American countries, their contribution to scientific publications on water quality is higher, but Asian countries are getting active in this area as well.

The strengths of this study are its relatively extended (over a decade) and broad scope of scientific contributions to public health research. One of the limitations of this study is the lack of review of published articles about water in other Iranian journals. However, most studies in this area appear to be published in specialised environmental health journals.

\section{Conclusion}

Despite the presence of water pollution and its adverse effects on human health, the health and economic system of the country, the number of papers published on the issue of water pollution was low. Health policymakers should therefore provide mechanisms for encouraging national researchers, especially environmental health professionals, by prioritising national research into water quality and pollution to encourage professionals to conduct studies in this regard.

\section{Supplementary information}

Supplementary information accompanies this paper at https://doi.org/10. 1186/s40550-020-00080-9.

Additional file 1 Attach 1. In the reviewed journals 52 articles were devoted to the determination of the amount and environmental effects of heavy metals in water resources, which are listed below for future research. (Ref.1-52).

\section{Additional file 2.}

\section{Abbreviations}

EHEMJ: Environmental Health Engineering and Management Journal; IJHE: Iranian Journal of Health and Environment; JEHE: Journal of Environmental Health Engineering; JEHSE: Journal of Environmental Health Science and Engineering; JREH: Journal of Research in Environmental Health; ICMJE: International Committee of Medical Journal Editors;

EPA: Environmental Protection Agency; WHO: World Health Organization; WSP: Water Safety Plan

\section{Acknowledgements}

Hereby, the cooperations of all the professors, students, and researchers whose articles published in journals as a source for this research, as well as the Deputy of Research and Technology of Gonabad University of Medical Sciences are highly appreciated. This study was registered and approved by the Code of Ethics (IR.GMU.REC.1396.110).

\section{Authors' contributions}

AT designed the study, made final decisions on the inclusion of journal articles and extracted data from them, and wrote and revised the manuscript. ZA conceived the study, made final decisions on the inclusion of journal articles and extracted data from them, and wrote and revised the manuscript. MS and HUD wrote and revised the manuscript. All authors read and approved the final manuscript. 


\section{Funding}

This research was funded by the Deputy of Research and Technology of Gonabad University of Medical Sciences. The funders did not have any role in the design of the study and collection, analysis, and interpretation of data and in writing the manuscript.

\section{Availability of data and materials}

The datasets used and analysed during the current study are available from the corresponding author on request.

\section{Ethics approval and consent to participate}

This study was approved and registered by the Code of Ethics (IR.GMU.REC.1396.110).

Consent for publication.

All authors agree to submit the above MS to the intended journal.

\section{Competing interests}

The authors declare that they have no competing interests. Permission to collect data.

We have a permission to collect the data from the source.

\section{Author details}

'Social Determinants of Health Research Center, Health Research Institute, Babol University of Medical Sciences, Babol, Iran. ${ }^{2}$ Faculty of Public Health, Gonabad University of Medical Sciences, Gonabad, Iran. Institute of Research and Development, Duy Tan University, Da Nang 550000, Vietnam. ${ }^{4}$ Faculty of Environment and Chemical Engineering, Duy Tan University, Da Nang 550000, Vietnam. ${ }^{5}$ School of Civil Engineering and Surveying, Faculty of Health, Engineering and Sciences, University of Southern Queensland, West Street, Toowoomba, 4350 QLD, Australia. ${ }^{6}$ Department of Chemical Engineering, School of Mining, Metallurgy and Chemical Engineering, University of Johannesburg, P. O. Box 17011, Doornfontein 2028, South Africa. ${ }^{7}$ Department of Biomedical Science and Environment Biology, College of Life Science, Kaohsiung Medical University, Kaohsiung, Taiwan. ${ }^{8}$ Research Center for Environmental Medicine, KMU - Kaohsiung Medical University, Kaohsiung 80708, Taiwan.

\section{Received: 20 December 2019 Accepted: 15 September 2020} Published online: 25 September 2020

\section{References}

Ab Razak NH, Praveena SM, Aris AZ, Hashim Z (2015) Drinking water studies: a review on heavy metal, application of biomarker and health risk assessment (a special focus in Malaysia) J. Epidemiol Glob Health 5:297-310. https://doi. org/. https://doi.org/10.1016/j.jegh.2015.04.003

Abraham MR, Susan TB (2017) Water contamination with heavy metals and trace elements from Kilembe copper mine and tailing sites in Western Uganda; implications for domestic water quality. Chemosphere. 169:281-287 https:// doi.org/10.1016/j.chemosphere.2016.11.077

Adesiyan IM, Bisi-Johnson M, Aladesanmi OT, Okoh Al, Ogunfowokan AO (2018) Concentrations and human health risk of heavy metals in Rivers in Southwest Nigeria. J Health Pollut 8(19):180907 https://doi.org/10.5696/2156-9614-8.19.180907

Aghalari Z, Dahms H, Sillanpää M, Sosa-Hernandez JE, Parra-Saldivar R (2020) Effectiveness of wastewater treatment systems in removing microbial agents: a systematic review. Glob Health 16(13) https://doi.org/10.1186/s12992-020-0546-y

Aghalari Z, Jafarian S. Survey of Nitrite and Nitrate in Mineral Water Available in the City of Babol in 2015. jehe 2017; 5 (1):65-72. https://doi.org/ https://doi. org/10.29252/jehe.5.1.65 (Abstract in English)

Aghalari Z, Tirgar A. Topics of Disasters in Scientific Outputs of Medical Sciences: A Cross-Sectional Study. HDQ. 2017; 2(2): 47-52. https://doi.org/https://doi. org/10.18869/nrip.hdq.2.2.47

Behailu BM, Pietilä PE, Katko TS (2016) Indigenous Practices of Water Management for Sustainable Services: Case of Borana and Konso, Ethiopia. SAGE Open 6(4) https://doi.org/10.1177/2158244016682292

Chen J, Li F, Fan Z, Wang Y (2016) Integrated application of multivariate statistical methods to source apportionment of watercourses in the Liao River basin, Northeast China. Int J Environ Res Public Health 13(10):1035 https://doi.org/ 10.3390/ijerph13101035

Dai B, Chen RC, Zhu SZ, Huang CY. A fuzzy recommendation system for daily water intake. Advances in Mechanical Engineering. 2016; 8 (5). https://doi. org/10.1177/1687814016649937
Fisher MB, Williams AR, Jalloh MF, Saquee G, Bain RE, Bartram JK (2015) Microbiological and chemical quality of packaged sachet water and household stored drinking water in Freetown, Sierra Leone. PLoS One 10(7): e0131772 https://doi.org/10.1371/journal.pone.0131772

Fu HZ, Wang MH, Ho YS (2013) Mapping of drinking water research: a bibliometric analysis of research output during 1992-2011. Sci Total Environ 443:757-765 https://doi.org/10.1016/j.scitotenv.2012.11.061

Glińska-Lewczuk K, Gołaś I, Koc J, Gotkowska-Plachta A, Harnisz M, Rochwerger A (2016) The impact of urban areas on the water quality gradient along a lowland river. Environ Monit Assess 188(11):624 https://doi.org/10.1007/s10661-016-5638-z

Hsieh JL, Nguyen TQ, Matte T, Ito K. Drinking water turbidity and emergency department visits for gastrointestinal illness in New York City, 2002-2009. PLoS One. 2015; 10(4):e0125071 Published 2015 Apr 28. https://doi.org/ https://doi.org/10.1371/journal.pone.0125071

ICMJE. Recommendations for the conduct, reporting, editing, and publication of scholarly work in medical journals. Updated December 2014. Available at http:// www.icmje.org/icmje-recomm endations.pdf. Accessed December 27, 2019

Ikonen J, Pitkänen T, Miettinen IT (2013) Suitability of optical, physical and chemical measurements for detection of changes in bacterial drinking water quality. Int J Environ Res Public Health 10(11):5349-5363 https//doi.org/10.3390/ijerph10115349

Kirschner AKT, Reischer GH, Jakwerth S et al (2017) Multiparametric monitoring of microbial faecal pollution reveals the dominance of human contamination along the whole Danube River. Water Res 124:543-555 https://doi.org/10. 1016/j.watres.2017.07.052

Komasi M, Sharghi S. Surface Water Quality Assessment and Prioritize the Factors Pollute This Water Using Topsis Fuzzy Hierarchical Analysis. Jehe. 2017; 4 (2): 174-184. https://doi.org/https://doi.org/10.18869/acadpub.jehe.4.2.174. (Abstract in English)

Li S, Xiao T, Zheng B (2012) Medical geology of arsenic, selenium and thallium in China Sci Total Environ 421-422:31-40 https://doi.org/10.1016/.scitotenv.2011.02.040

Sajjadi SA, Tirgar A, Aghalari Z (2018) A content analysis of articles published in recent decade in environmental health journals with an emphasis on air pollution. J Air Poll Health 3(4):177-186 https://doi.org/10.18502/japh.v3i4.393

Satterthwaite D (2016) Missing the millennium development goal targets for water and sanitation in urban areas. Environ Urban 28(1):99-118 https://doi. org/10.1177/0956247816628435

Sweileh WM, Zyoud SH, Al-Jabi SW, Sawalha AF, Shraim NY (2016) Drinking and recreational water-related diseases: a bibliometric analysis (1980-2015). Ann Occup Environ Med 28(1):40 https://doi.org/10.1186/s40557-016-0128-x

The United Nations world water development report 2015: water for a sustainable world; ISBN:978-92-3-100071-3, 978-92-3-100099-7 (ePub)

Tirgar A, Aghalari Z (2018) Scientific Achievements of Medical Journals in Occupational Accidents. HDQ 3(4):179-184. https://doi.org/. https://doi.org/ 10.32598/hdq.3.4.179

Tirgar A, Sajjadi SA, Aghalari Z (2019) The status of international collaborations in compilation of Iranian scientific articles on environmental health engineering. Glob Health 15(1):17. https://doi.org/. https:/doi.org/10.1186/s12992-019-0460-3

Van Eck NJ, Waltman L (2009) VOSviewer: A computer program for bibliometric mapping. In: Larsen B, Leta J (eds) Proceedings of the 12th international conference on Scientometrics and Informetrics, pp 886-897 https://doi.org/ 10.1007/s11192-009-0146-3

WHO (2014) Preventing Diarrhoea Through Better Water, Sanitation and Hygiene. World Health Organization, Geneva

World Association of Medical Editors (WAME), Editorial Policy and Publication Ethics Committees. Conflict of interest in peer-reviewed medical journals. WAME Web site. http://www.wame.org/conflict-of-interest-in-peer-reviewedmedical-journals. Accessed December 27, 2019

World Health Organization. Guidelines for drinking-water quality. 3rd ed. vol. 1. Geneva: WHO; 2008

Yan CA, Zhang W, Zhang Z, Liu Y, Deng C, Nie N (2015) Assessment of water quality and identification of polluted risky regions based on field observations \& GIS in the Honghe River watershed, China. PLoS One 10(3): e0119130 https://doi.org/10.1371/journal.pone.0119130

Yao H, Zhuang W, Qian Y, Xia B, Yang Y, Qian X (2016) Estimating and predicting metal concentration using online turbidity values and water quality models in two Rivers of the Taihu Basin, Eastern China. PLoS One 11(3):e0152491. https://doi.org/10.1371/journal.pone.0152491H

\section{Publisher's Note}

Springer Nature remains neutral with regard to jurisdictional claims in published maps and institutional affiliations. 